\title{
Immunological studies in cows' milk protein-sensitive enteropathy
}

\author{
M YADAV AND N IYNGKARAN \\ Department of Genetics and Cellular Biology, University of Malaya, Kuala Lumpur, and Department of \\ Paediatrics, University Hospital, Kuala Lımpur, Malaysia
}

SUMMARY 55 infants, aged between 1 and 13 months, who presented with persistent diarrhoea were placed on a diet free of cows' milk protein. The clinical condition of the infants improved and 6-8 weeks later each was challenged with low-lactose cows' milk. The following investigations were performed before and 24 hours after provocation: jejunal biopsy, serum and duodenal juice levels of complement C3 and C4, C3-activator, and immunoglobulins A, G, M, and D. Three groups were recognised on postchallenge clinical symptoms together with histological changes in the jejunal mucosa: group 1 ( $n=10$ infants) with no clinical or mucosal abnormality, group 2 ( $n=18$ infants) with mucosal abnormalities but lacking clinical symptoms, and group 3 ( $n=27$ infants) with mucosal abnormalities and clinical symptoms; but in group 3 symptoms were delayed for over 24 hours in 7 infants, and in the remaining 20 infants symptoms appeared within 24 hours. After provocation the serum IgG levels were decreased in 3 infants in group 1, 12 in group 2, and 17 in group 3 . The mean serum IgA and IgM levels were higher in group 1 compared with group 2 or 3; pre- and postchallenge mean serum immunoglobulin levels, complement, and complement activator levels were of equal magnitude in all three groups. A depletion of serum complement $\mathrm{C} 3$ level was observed in 4 (group 1), 4 (group 2), and 13 (group 3) infants 24 hours after provocation with cows' milk; the fall in serum IgG was often associated with depletion of complement in serum. This suggests the involvement in some infants of IgG-mediated complement-consuming immune reactions in the development of the damage in the intestinal mucosa. After challenge, exudation of $\operatorname{IgG}$ and $\operatorname{IgA}$ occurred irrespective of the presence or absence of mucosal damage and was not always associated with the decrease in serum IgG concentration. Because of the variable conditions present in the intestinal lumen it is suggested that the level of immunoglobulins in duodenal juice is not a reliable measure of the local immune response. Levels of complement and immunoglobulin in serum or duodenal juice fail to provide help in the diagnosis of cows' milk protein-sensitive enteropathy.

A small proportion of young infants fed on cows' milk develop cows' milk protein-sensitive enteropathy (CMPSE), clinically characterised by failure to thrive, vomiting, diarrrhoea, and malabsorption. ${ }^{1-3}$ If cows' milk is excluded from the diet there is soon an improvement, and relapse may be induced by reintroduction of cows' milk or milk protein components, especially $\beta$-lactoglobulin. ${ }^{4}$ The pathogenesis of cows' milk-induced intestinal mucosal damage remains uncertain. It has been suggested that cows' milk intolerance develops as a consequence of increased intestinal permeability to intraluminal antigens, which then provoke a systemic immune response. ${ }^{5-6}$ Several factors-such as transient or selective IgA deficiency, damaged mucosal barrier, lysosomal dysfunction, or abnormal intraluminal digestion-have been implicated as contributing to the pathological absorption of the macromolecules. ${ }^{7}$ The involvement of several different types of immunological mechanisms in the pathogenesis of cows' milk intolerance has been shown. ${ }^{3}$ 8-15

Iyngkaran et al. ${ }^{16}$ proposed an alternative approach to diagnosing CMPSE, using clinical and histological criteria. We have applied these criteria to study the changes in the immunoglobulin and complement levels in sera of infants before and after cows' milk challenge.

\section{Materials and methods}

Patients. The series consisted of 55 infants clinically suspected to be intolerant of cows' milk protein. 
Initially cows' milk was eliminated from the diet and a formula free of cows' milk was substituted (Pregestimil, Prosobee, Sobee, or Nutramigen). If a satisfactory response was obtained, judged by lack of symptoms and satisfactory weight gain, the infant was discharged and the parents instructed not to introduce any new food without our knowledge. The weight gains were maintained satisfactorily on this diet and at the end of 6 to 8 weeks the infant was readmitted for further tests (Table 1 ).

Cows' milk challenge and jejunal biopsy. The challenge studies were performed as described previously. ${ }^{17}$ Duodenal juice was collected at the time of the biopsy via a biopsy tube. The juice was stored at $-20^{\circ} \mathrm{C}$ after the addition of antitrypsin (Sigma, St Louis) at a concentration of $1 \mathrm{mg} / \mathrm{ml}$ juice.

Blood samples. Blood in heparin was taken immediately before the oral challenge and then at 90 minutes and 4, 12, and 24 hours after it. This paper reports on the data of prechallenge and postchallenge blood at 24 hours. Blood analyses consisted of the estimation by standard methods of haemoglobulin concentration, total and differential white cell counts. The serum samples were kept at $-20^{\circ}$ until used. For complement assays the serum was thawed not more than twice.

Assay for immunoglobulins and complement. Immunoglobulin $\mathrm{G}, \mathrm{A}, \mathrm{M}$, and $\mathrm{D}$, complement $\mathrm{C} 3$ and $\mathrm{C} 4$, and $\mathrm{C} 3$-activator were measured by the radial immunodiffusion technique of Mancini et al. ${ }^{18}$ on specific immunoplates (Behringwerke, Germany); the reference standard also came from Behringwerke. The standard for IgA consisted of the monomeric form which was used in serum and duodenal juice assays (Behringwerke). Special plates were used for assay of low concentration of immunoglobulins and complement in the duodenal juice. The instructions of the supplier were followed for the assays.

\section{Results}

Clinical symptoms on cows' milk provocation. The clinical data and the onset of symptoms after milk challenge in the 55 patients are summarised (Table 1). On the basis of pathological changes in the jejunal biopsy at 21 to 24 hours, and the time taken before the onset of clinical symptoms (especially diarrhoea), the patients were classified into three groups.

Group $1(n=10)$

These infants had no mucosal abnormalities or clinical symptoms and could effectively be considered as the control for the series. The original diarrhoea might have been due to causes other than cows' milk. The mean age of these infants was greater than the infants in groups 2 or 3 , but the range of ages at admission was similar.

Group $2(n=18)$

These infants had mucosal abnormalities but no clinical symptoms.

Group $3(n=27)$

These infants had mucosal abnormalities and clinical symptoms; in 7 these symptoms were delayed by over 24 hours, in 20 they appeared within 24 hours.

We analysed the data on the basis of these groups since we believed that they formed a clear classification. Enteropathogenic organisms were isolated from the prechallenge stools of 3 infants (Salmonella sp.) of group 1, 5 infants (4 Escherichia coli, Salmonella sp.) of group 2, and 4 infants (Salmonella sp.) of group 3.

Changes in serum immunoglobulin and complement levels after cows' milk challenge. Immunoglobulins

Table 1 Clinical features of 55 infants with diarrhoea at first admission

\begin{tabular}{|c|c|c|c|}
\hline & Group I $(n=10)$ & Group $2(n=18)$ & Group $3 \quad(n=27)$ \\
\hline $\begin{array}{l}\text { Age at admission (weeks) } \\
\text { Boys:girls } \\
\text { Chinese/Indian/Malays } \\
\text { Birthweight (kg) } \\
\text { Weight at admission (kg) } \\
\text { Age at onset (weeks) } \\
\text { Total duration of diarrhoea (days) } \\
\text { Weight } 8 \text { weeks after admission and before challenge (kg) } \\
\text { Clinical symptoms } \\
\text { Mucosal histology rating, prechallenge/postchallenge }\end{array}$ & $\begin{array}{l}22 *(1-46) \\
7: 3 \\
7 \dagger / 0 / 3 \\
3 \cdot 1(2 \cdot 3-3 \cdot 5) \\
5 \cdot 9(2 \cdot 7-9 \cdot 3) \\
21 \cdot 6(1-46) \\
8 \cdot 2(1-30) \\
7 \cdot 02(4 \cdot 3-9 \cdot 45) \\
\text { None } \\
4 \cdot 3(0-9) / 3 \cdot 8(0-9) ף\end{array}$ & $\begin{array}{l}7 \cdot 5 *(0 \cdot 5-20) \\
11: 7 \\
9 / 1 / 8 \\
3 \cdot 0(1 \cdot 4-4) \\
3 \cdot 6(1 \cdot 5-6 \cdot 3) \\
6 \cdot 1(0 \cdot 5-20) \\
6 \cdot 7(1-35) \\
4 \cdot 93(4-7 \cdot 1) \\
\text { None } \\
2 \cdot 53(0-7) / 8 \cdot 64(5-11)\end{array}$ & $\begin{array}{l}9 \cdot 8^{*}(1-56) \\
12: 15 \\
14 \ddagger / 9 / 3 \\
2 \cdot 9(2 \cdot 0-3 \cdot 8) \\
3 \cdot 6(1 \cdot 7-9 \cdot 5) \\
5(0 \cdot 14-50) \\
17 \cdot 2(1-56) \\
5 \cdot 62(3 \cdot 6-9 \cdot 6) \\
\text { Diarrhoea }(27) \S \\
2 \cdot 04(0-6) / 10 \cdot 1(5-13)\end{array}$ \\
\hline
\end{tabular}

* Mean, range is shown in parentheses. †Mixed race, Malay father and Chinese mother; $\ddagger$ mixed race, Indian father and Chinese mother.

$\$$ Reintroduction of milk caused diarrhoea within a few hours ( $<24$ hours) in 20 infants; clinical symptoms (including diarrhoea) were delayed (1-14 days) in 7 infants.

Tucosal histology was numerically rated as follows: normal 0-3, slightly abnormal 4-7, moderately abnormal 8-11, and severely abnormal 11-16. Postchallenge biopsy was taken $23-24$ hours after the initial (prechallenge) biopsy.16 


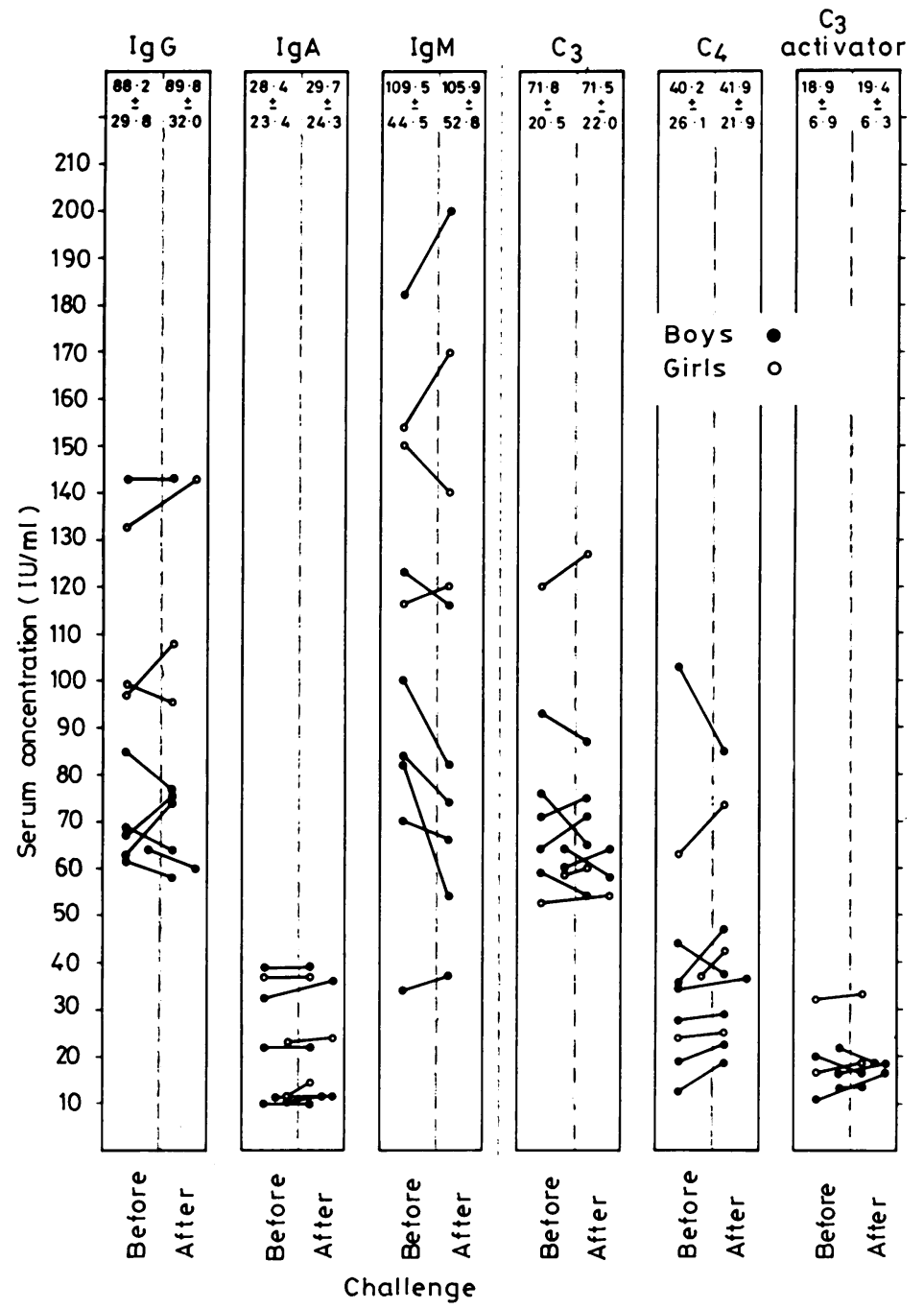

Fig. 1 Group 1. Immunoglobulin and complement levels in serum assayed before challenge with cow's' milk and 24 hours later in 10 infants who were on a hypoallergenic formula for 6-8 weeks. Infants at admission presented with various symptoms (including diarrhoea) which resolved when milk proteins were eliminated, and the challenge with cows' milk produced no clinical symptoms or jejunal mucosal abnormality. Mean $\pm S D$ given at top of bar.
(G, A, M, and D), complement (C3, C4), and C3activator levels were assayed in serum just before and 24 hours after provocation with cows' milk. After provocation, the serum IgG level in 3 infants in group 1 (Fig. 1), in 12 infants in group 2 (Fig. 2), and in 17 infants in group 3 (Fig. 3) were decreased; in other infants the levels were unchanged or slightly increased. The mean serum IgG level in serum before and after the challenge in the three groups was of equal magnitude.

The mean serum IgA and IgM levels were higher in group 1 than in groups 2 or 3 , but in none of the groups was there any difference in the serum level before or after challenge.

The mean complement $\mathrm{C} 3$ and $\mathrm{C} 4$ and $\mathrm{C} 3$-activator levels of serum were of equal magnitude in the three groups and no significant difference was noted in pre- and postchallenge results.

The serum IgD levels were also assayed but they could be detected in only about $10 \%$ of the infants and the results did not show any association with CMPSE.

Table 2 summarises the change in serum IgG in relation to the changes observed in complement $\mathrm{C} 3$ before and after challenge with cows' milk. Fall in IgG after challenge was noted in about two-thirds of the infants in groups 2 and 3, and in one-third of the infants in group 1. It ranged from 9 to $28 \%$ for all three groups. The mean serum IgG level in general was highest in infants in whom IgG levels fell after challenge and was lowest in infants in whom the IgG levels did not change. 


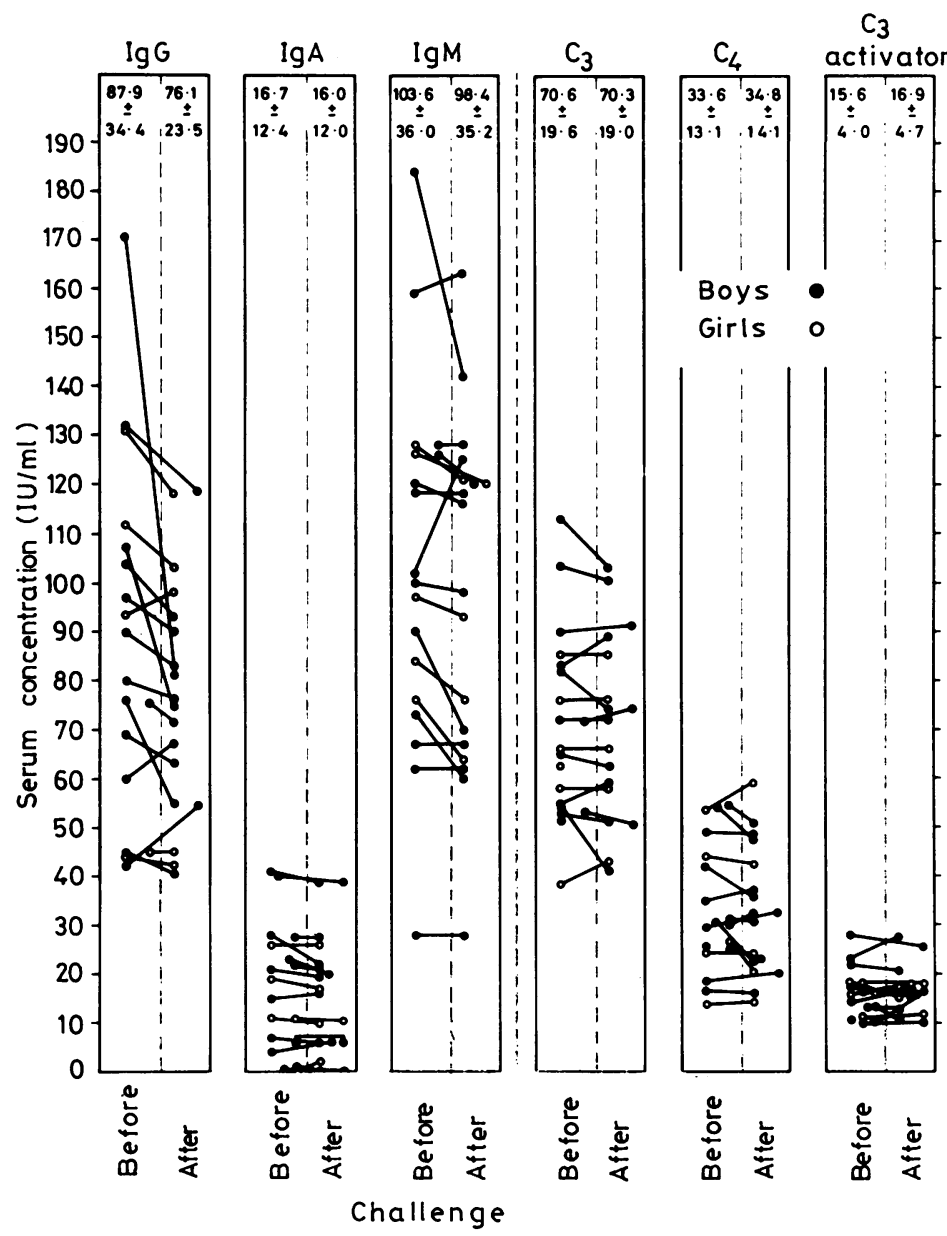

Fig. 2 Group 2. Immunoglobulin and complement levels in serum assayed before challenge with cows' milk and 24 hours later in 18 infants who were on a hypoallergenic formula for 6-8 weeks. Infants at admission presented with various symptoms (including diarrhoea) which resolved when milk proteins were eliminated, and the re-exposure to cows' milk produced no clinical symptoms but histologically the jejunal mucosa was moderately changed.

Table 2 Changes in serum immunoglobulin IgG and complement C3 levels 24 hours after intestinal provocation with cows' milk

\begin{tabular}{|c|c|c|c|c|c|c|c|c|c|c|c|c|}
\hline \multirow{2}{*}{$\begin{array}{l}\text { Challenge } \\
\text { changes }\end{array}$} & \multicolumn{4}{|c|}{ Group 1} & \multicolumn{4}{|c|}{ Group 2} & \multicolumn{4}{|c|}{ Group 3} \\
\hline & $n$ & $\begin{array}{l}\text { Pre- } \\
\text { challenge }\end{array}$ & $\begin{array}{l}\text { Post- } \\
\text { challenge }\end{array}$ & $\begin{array}{l}\% \\
\text { change }\end{array}$ & $n$ & $\begin{array}{l}\text { Pre- } \\
\text { challenge }\end{array}$ & $\begin{array}{l}\text { Post- } \\
\text { challenge }\end{array}$ & $\begin{array}{l}\% \\
\text { change }\end{array}$ & $n$ & $\begin{array}{l}\text { Pre- } \\
\text { challenge }\end{array}$ & $\begin{array}{l}\text { Post- } \\
\text { challenge }\end{array}$ & $\begin{array}{l}\% \\
\text { change }\end{array}$ \\
\hline IgG decrease & 3 & $72 \cdot 7 \pm 11^{*}$ & $66 \cdot 3 \pm 8 \cdot 9$ & $-8 \cdot 8$ & 4 & $117 \pm 43$ & $84 \cdot 3 \pm 25 \cdot 9$ & $-27 \cdot 9$ & 10 & $108 \cdot 4 \pm 56 \cdot 8$ & $94 \cdot 3 \pm 40 \cdot 7$ & -13 \\
\hline $\begin{array}{l}\text { C3 decrease } \\
\text { IgG decrease }\end{array}$ & & $67 \cdot 0 \pm 8 \cdot 9$ & $59 \pm 5 \cdot 6$ & $-11 \cdot 9$ & 8 & $\begin{array}{l}78 \cdot 5 \pm 25 \\
93 \cdot 1 \pm 27 \cdot 2\end{array}$ & $\begin{array}{l}70 \cdot 0 \pm 25 \cdot 9 \\
82 \cdot 3 \pm 24 \cdot 2\end{array}$ & $\begin{array}{r}-10 \cdot 8 \\
-11 \cdot 6\end{array}$ & 7 & $\begin{array}{l}80 \cdot 9 \pm 17 \cdot 0 \\
88 \cdot 6 \pm 32 \cdot 2\end{array}$ & $\begin{array}{l}67 \cdot 1 \pm 11 \cdot 9 \\
78 \cdot 6 \pm 26 \cdot 7\end{array}$ & $\begin{array}{l}-17 \cdot 1 \\
-11 \cdot 3\end{array}$ \\
\hline $\begin{array}{l}\text { C3 no change/ } \\
\text { increase } \\
\text { IgG no change/ }\end{array}$ & & & & & & $62 \cdot 3 \pm 13 \cdot 3$ & $62 \cdot 4 \pm 13 \cdot 9$ & $-0 \cdot 2$ & & $59 \cdot 7 \pm 22 \cdot 4$ & $60 \cdot 2 \pm 22 \cdot 6$ & +0.8 \\
\hline increase & 1 & 143 & 143 & 0 & 0 & & & & 3 & $70 \cdot 5 \pm 35 \cdot 2$ & $79 \cdot 7 \pm 32 \cdot 7$ & +13 \\
\hline $\begin{array}{l}\text { C3 decrease } \\
\text { IgG no change/ }\end{array}$ & & 93 & 87 & $-6 \cdot 5$ & & & & & & $84 \cdot 8 \pm 31 \cdot 0$ & $76 \cdot 5 \pm 28 \cdot 8$ & $-9 \cdot 8$ \\
\hline increase & 6 & $81 \cdot 5 \pm 29 \cdot 0$ & $95 \cdot 9 \pm 38 \cdot 1$ & $+17 \cdot 7$ & 6 & $60 \cdot 0 \pm 20 \cdot 8$ & $63 \cdot 0 \pm 20 \cdot 7$ & +5 & 7 & $65 \cdot 6 \pm 11 \cdot 2$ & $70 \cdot 6 \pm 17 \cdot 7$ & $+7 \cdot 6$ \\
\hline $\begin{array}{l}\text { C3 no change/ } \\
\text { increase }\end{array}$ & & $59 \cdot 1 \pm 4 \cdot 0$ & $74 \cdot 4 \pm 27 \cdot 3$ & $+25 \cdot 9$ & & $76 \cdot 3 \pm 21 \cdot 5$ & $78 \cdot 0 \pm 19 \cdot 6$ & $+2 \cdot 2$ & & $64 \cdot 1 \pm 17 \cdot 0$ & $68 \cdot 1 \pm 17 \cdot 9$ & $+6 \cdot 2$ \\
\hline
\end{tabular}

*Mean $\pm \mathrm{SD}$, values of $\mathrm{IgG}(\mathrm{IU} / \mathrm{ml})$ and $\mathrm{C3}(\mathrm{mg} / 100 \mathrm{ml})$ obtained before challenge feed of cows' milk and 24 hours later. 


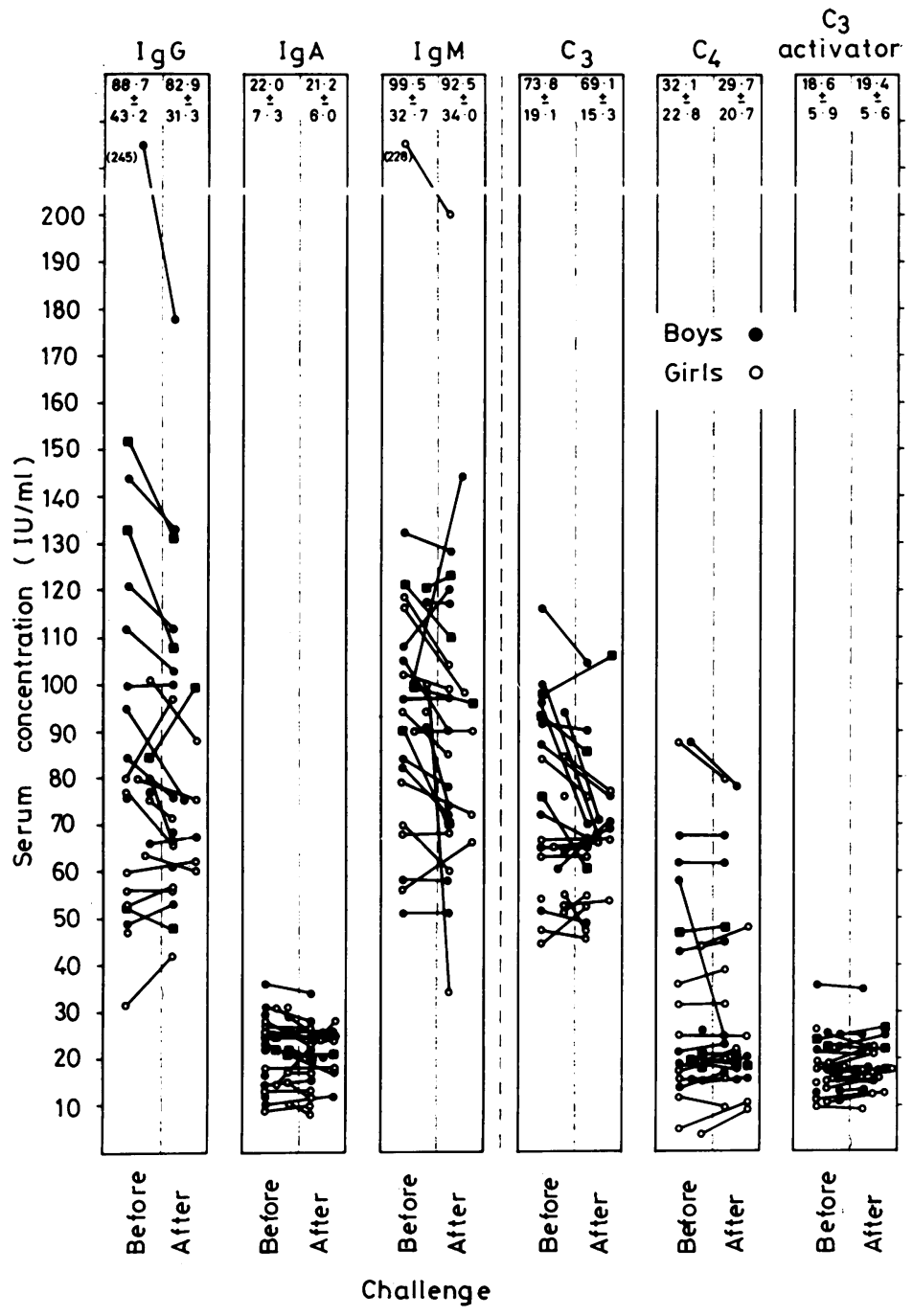

Fig. 3 Group 3. Immunoglobulin and complement levels in serum assayed before challenge with cows' milk and 24 hours later in 27 infants who were on a hypoallergenic formula for 6-8 weeks. Infants at admission presented with various symptoms (including diarrhoea) which resolved when milk proteins were eliminated and the re-exposure to cows' milk produced diarrhoea and severe histological abnormalities in jejunal mucosa.

Changes in duodenal juice immunoglobulin and complement levels after cows' milk challenge. Pre- and postchallenge duodenal juices were obtained in 4 infants from group 1, in 7 infants from group 2, and in 8 infants from group 3, and these juices were assayed for IgG, IgA, IgM, IgD, and complement C3 and the information is summarised (Table 3 ) in relation to the fall or increase in serum IgG concentration. The juices were analysed for complement $\mathrm{C} 4$ and $\mathrm{C} 3$ activator too, but these components were absent from most of the juices assayed.

Fall in serum IgG after the challenge was associated with increased exudation of IgG in the duodenal juice in groups 2 and 3 , but exudation also occurred in the absence of decrease in serum IgG in groups 1 and 3 . In addition, fall in serum IgG after challenge was associated with exudation of $\operatorname{IgA}$ and IgM in the juice in the three groups, but exudation of IgA in group 1 and of IgM in group 2 occurred in the absence of decrease in serum IgG. Complement C3 levels decreased in group 3 regardless of whether there was a fall in serum IgG after challenge. In groups 1 and 2 , the increase in complement $\mathrm{C} 3$ exudation was associated with a fall of serum IgG.

\section{Discussion}

The immunological mechanisms involved in the small-bowel mucosal damage of CMPSE remains uncertain, but it is possible that several types of 
Table 3 Immunoglobulin and complement levels in duodenal juice before challenge and 24 hours later in relation to changes in serum IgG after provocation

\begin{tabular}{|c|c|c|c|c|c|c|c|}
\hline \multirow{2}{*}{$\begin{array}{l}\text { Change in serum IgG } \\
\text { after challenge }\end{array}$} & \multirow{2}{*}{$\begin{array}{l}\text { No } \\
\text { studied }\end{array}$} & \multicolumn{5}{|c|}{ Duodenal juice immunoglobulin levels $\left(I U / \mathrm{ml}^{*}\right)$} & \multirow{2}{*}{ Complement $(\mathrm{mg} / \mathrm{ml})$} \\
\hline & & & $G$ & $\boldsymbol{A}$ & $M$ & $D$ & \\
\hline \multicolumn{8}{|l|}{ Group 1} \\
\hline Decrease & 1 & $\begin{array}{l}\text { Prechallenge } \\
\text { Postchallenge } \\
\% \text { change }\end{array}$ & $\begin{array}{l}0.91 \\
0.7 \\
-23\end{array}$ & $\begin{array}{l}7 \cdot 8 \\
11 \cdot 2 \\
+44\end{array}$ & $\begin{array}{l}6 \cdot 75 \\
5 \cdot 2 \\
+23\end{array}$ & $\begin{array}{l}75 \\
81 \\
+8\end{array}$ & $\begin{array}{l}57 \\
70 \cdot 5 \\
+24\end{array}$ \\
\hline No change/increase & 3 & $\begin{array}{l}\text { Prechallenge } \\
\text { Postchallenge } \\
\% \text { change }\end{array}$ & $\begin{array}{l}0.72 \pm 0.37 \\
1 \cdot 05 \pm 0.31 \\
+46\end{array}$ & $\begin{array}{l}3 \cdot 25 \pm 1 \cdot 56 \\
5 \cdot 53 \pm 6 \cdot 34 \\
+70\end{array}$ & $\begin{array}{l}3 \cdot 48 \pm 1 \cdot 24 \\
5 \cdot 3 \pm 2 \cdot 7 \\
-52\end{array}$ & $\begin{array}{l}57 \cdot 8 \pm 5 \cdot 51 \\
40 \cdot 0 \pm 15 \cdot 6 \\
-31\end{array}$ & $\begin{array}{l}48 \cdot 0 \pm 11 \cdot 7 \\
37 \cdot 8 \pm 16 \cdot 6 \\
-21\end{array}$ \\
\hline \multicolumn{8}{|l|}{ Group 2} \\
\hline Decrease & 6 & $\begin{array}{l}\text { Prechallenge } \\
\text { Postchallenge } \\
\% \text { change }\end{array}$ & $\begin{array}{l}1 \cdot 01 \pm 0.48 \\
2 \cdot 01 \pm 2 \cdot 33 \\
+99\end{array}$ & $\begin{array}{l}3 \cdot 68 \pm 1 \cdot 32 \\
4 \cdot 40 \pm 2 \cdot 81 \\
+20\end{array}$ & $\begin{array}{l}7 \cdot 82 \pm 7 \cdot 44 \\
10 \cdot 48 \pm 10 \cdot 31 \\
+37\end{array}$ & $\begin{array}{l}9 \cdot 7 \pm 13 \cdot 5 \\
44 \cdot 6 \pm 70 \cdot 4 \\
+360\end{array}$ & $\begin{array}{l}2 \cdot 25 \pm 5 \cdot 04 \\
8 \cdot 58 \pm 12 \cdot 08 \\
+281\end{array}$ \\
\hline No change/increase & 1 & $\begin{array}{l}\text { Prechallenge } \\
\text { Postchallenge } \\
\% \text { change }\end{array}$ & $\begin{array}{l}0.96 \\
0.28 \\
-71\end{array}$ & $\begin{array}{l}14 \\
-9\end{array}$ & $\begin{array}{l}15 \cdot 2 \\
+81\end{array}$ & $\begin{array}{l}138 \\
37 \cdot 5 \\
-73\end{array}$ & $\begin{array}{l}121 \\
59 \cdot 5 \\
-51\end{array}$ \\
\hline \multicolumn{8}{|l|}{ Group 3} \\
\hline Decrease & 4 & $\begin{array}{l}\text { Prechallenge } \\
\text { Postchallenge } \\
\% \text { change }\end{array}$ & $\begin{array}{l}1 \cdot 61 \pm 2 \cdot 24 \\
2 \cdot 29 \pm 1 \cdot 42 \\
+42\end{array}$ & $\begin{array}{l}5 \cdot 75 \pm 2 \cdot 85 \\
5 \cdot 83 \pm 4 \cdot 29 \\
+1\end{array}$ & $\begin{array}{l}5 \cdot 13 \pm 5 \cdot 84 \\
6 \cdot 4 \pm 3 \cdot 49 \\
+24\end{array}$ & $\begin{array}{l}41 \pm 20 \\
13 \cdot 3 \pm 23 \\
-68\end{array}$ & $\begin{array}{l}48 \cdot 5 \pm 61 \cdot 7 \\
37 \pm 46 \cdot 6 \\
-24\end{array}$ \\
\hline No change/increase & 4 & $\begin{array}{c}\text { Prechallenge } \\
\text { Postchallenge } \\
\% \text { change }\end{array}$ & $\begin{array}{l}1 \cdot 01 \pm 1 \cdot 39 \\
1 \cdot 73 \pm 1 \cdot 94 \\
+71\end{array}$ & $\begin{array}{l}4 \cdot 09 \pm 2 \cdot 24 \\
3 \cdot 40 \pm 2 \cdot 27 \\
-17\end{array}$ & $\begin{array}{l}4 \cdot 18 \pm 0 \cdot 33 \\
3 \cdot 62 \pm 3 \cdot 14 \\
-13\end{array}$ & $\begin{array}{l}100 \cdot 7 \pm 48 \cdot 2 \\
13 \cdot 3 \pm 13 \cdot 7 \\
-87\end{array}$ & $\begin{array}{l}81 \cdot 6 \pm 51 \cdot 2 \\
23 \cdot 1 \pm 18 \cdot 6 \\
-77\end{array}$ \\
\hline
\end{tabular}

*Mean \pm SD.

immune hypersensitivity reactions are affected, independently or together. The demonstration of immunoglobulins and complement deposits in the intestinal mucosa of infants with CMPSE ${ }^{13}$ suggests that complement participates through its activation by antibody-antigen complexes in the gut. Matthews and Soothill ${ }^{15}$ found that of 8 infants studied with cows' milk protein intolerance, 5 whose symptoms were largely intestinal had evidence of complement C3 activation on challenge with cows' milk. Savilahti, ${ }^{12}$ on the other hand, was unable to demonstrate a fall in complement levels in serial blood samples taken after challenge from 6 infants with CMPSE who developed clinical symptoms. Our data show that after intestinal milk challenge, serum IgG concentration fell in $30 \%$ of infants who had no clinical or histological signs of CMPSE (group 1), in $63 \%$ of those who had mucosal damage but no clinical signs (group 2), and in $67 \%$ of those with both mucosal damage and clinical signs (group 3 ). Moreover, in many of these infants the fall in serum IgG after challenge was associated with depletion of serum complement C3. This suggests that in some infants the development of mucosal damage after cows' milk challenge might have been associated with the formation of IgG antibodyantigen complexes which are phlogistic. The resulting mucosal damage might be followed by exudation of serum proteins. However, the depletion of serum IgG and complement $\mathrm{C} 3$ in infants who did not have CMPSE indicates that exudation can occur in the absence of mucosal damage.
The absence of change in serum C3-activator after cows' milk protein challenge in infants with mucosal damage suggests a minimal role for the alternate pathway as a link between the immune complexes and pathogenesis. No consistent decrease in serum complement $\mathrm{C} 3$ occurred in many of the infants who developed severe mucosal damage on challenge with cows' milk protein. In these infants, other forms of immune interactions may be operative involving complement $\mathrm{C} 3$ only to a minor extent.

Variable levels of complement $\mathrm{C} 3$ were present in the duodenal juice, and since the levels of other complements were low, the cascade would not be able to go to completion. Therefore, functionally the role of $\mathrm{C} 3$ in the duodenal juice is limited under these adverse conditions. However, if the $\mathrm{C} 3$ binds to antibody-antigen complexes, through the classical or alternate pathway, it would enhance phagocytosis of the complexes by lumen macrophages.

It has been suggested that IgA deficiency may form the primary predisposing factor in the development of CMPSE. ${ }^{219-20}$ Our data show lower (but nonsignificant) mean serum IgA and IgM levels in groups 2 and 3 compared with group 1 . In addition, the levels of duodenal juice IgA were of a similar magnitude in the three groups. In contrast to groups 1 and 3 who had normal IgA levels, very low serum IgA levels were present in group 2 infants. This is surprising since infants in group 3 were the ones who developed the most severe mucosal damage on milk challenge. However, our observations did not exclude the possibility of a transient IgA deficiency in early 
infancy; about $65 \%$ of Malaysian newborn infants lack serum $\operatorname{IgA} .^{21}$

Freier ${ }^{8}$ found increased levels of IgM in the gut of $30 \%$ of infants with cows' milk protein allergy, and he suggested that IgM was able to replace IgA on the mucosal surface. We found no increased concentration of IgM in the duodenal juice. After challenge the IgG levels in the duodenal juice were raised compared with prechallenge values and thus the IgG:IgM concentration ratios were increased in the three groups. This may indicate nonspecific protein loss as a consequence of mucosal damage rather than secretion of the immunoglobulin. ${ }^{22}$

Interestingly, IgD was present in the duodenal juice; the mean levels were lower in postchallenge duodenal juice compared with prechallenge levels: the significance of this is not clear.

Although we need better methods in diagnosing CMPSE, the present study shows that the assay of immunoglobulin and complement levels in the serum and duodenal juice is not useful in this context. The fall in serum IgG after intestinal cows' milk provocation is not a consistent feature in CMPSE, and a fall in serum IgG was observed also in a control group with no specific features of CMPSE. Exudative enteropathy is known not to be exclusive to situations with mucosal damage present, and this may be because it is hard to detect the proteins in the variable conditions prevalent in the gut lumen.

We thank the nursing staff for co-operation, and $\mathrm{Mr}$ P Thirukumar and Mrs Irene Seow for technical assistance.

The work was supported by the University of Malaya Research Grants Committee, and some facilities were generously provided by Bristol Meyers, New York, USA, and the World Health Organisation.

\section{References}

1 Goldman A S, Anderson D W, Jr, Sellers W A, Saperstein S, Kniker W T, Halpern S R. Milk allergy. I. Oral challenge with milk and isolated milk proteins in allergic children. Pediatrics $1963 ; 32$ : 425-43.

2 Gerrard J W, MacKenzie J W A, Goluboff N, Sarson J Z, Maningas C S. Cows' milk allergy: prevalence and manifestation in an unselected series of newborns. Acta Paediatr Scand (Suppl) 1973; 234: 1-21.

3 Kuitunen P, Visakorpi J K, Savilahti E, Pelkonen P. Malabsorption syndrome with cows' milk intolerance: clinical findings and course in 54 cases. Arch Dis Child 1975; 50: 351-6.

4 Fontaine J L, Navarro J. Small intestinal biopsy in cows' milk protein allergy in infancy. Arch Dis Child 1975; 50: 357-62.

5 Sutton R E, Hamilton J R. Tolerance of young children with severe gastroenteritis to dietary lactose: a controlled study. Can Med Assoc J 1968; 99: 980-2.

${ }^{6}$ Rothberg R M, Kraft S C, Farr R S, Kriebel G W, Goldberg S S. Local immunologic responses to ingested protein. In: Dayton D, ed. The secretory immunologic system. Bethesda, Maryland: National Institute of Child Health and Human Development, 1970: 293-307.

7 Walker W A. Antigen absorption from the small intestine and gastrointestinal disease. Pediatr Clin North Am 1975; 22: 731-46.

8 Freier S. Paediatric gastrointestinal allergy. In: Brostoff J, ed. Clinical immunology-allergy in paediatric medicine. Oxford: Unigate/Blackwell Scientific, 1973.

9 Gunther M, Aschaffenburgh R, Matthews R H, Parish W E, Coombs RRA. The levels of antibodies to the proteins of cows' milk in the serum of normal human infants. Immunology 1960; 3: 296-306.

10 Peterson R D, Good R A. Antibodies to cows' milk proteins: their presence and significance. Pediatrics 1963; 31 : 209-21.

11 Kletter B, Gery I, Freier S, Davies A M. Immune responses of normal infants to cow milk. I. Antibody type and kinetics of production. Int Arch Allergy App! Immunol 1971; 40: 556-66.

12 Savilahti E. Immunochemical study of the malabsorption syndrome with cows' milk intolerance. Gut 1973; 14: 491-501.

13 Shiner M, Ballard J, Brook C G D, Herman S. Intestinal biopsy in the diagnosis of cows' milk protein intolerance without acute symptoms. Lancet 1975; ii: 1060-3.

14 Brenchley P E C. IgE in milk allergy. Postgrad Med J 1975; 51 : Supplement 3, 76-8.

15 Matthew's T S, Soothill J E. Complement activation after milk feeding in children with cows' milk allergy. Lancet 1970 ; ii: $893-5$.

16 Jyngkaran N, Robinson M J, Prathap K, Sumithran E, Yadav M. Cows' milk protein-sensitive enteropathy: combined clinical and histological criteria for diagnosis. Arch Dis Child 1978; 53: 20-6.

17 Iyngkaran N, Davis K, Robinson M J, et al. Cows' milk protein-sensitive enteropathy. An important contributing cause of secondary sugar intolerance in young infants with acute infective enteritis. Arch Dis Child 1979; 54: 39-43.

18 Mancini G, Carbonara A O, Heremans J F. Immunochemical quantitation of antigens by single radial immunodiffusion. Immunochemistry 1965; 2 : 235-54.

19 Taylor K B, Truelove S C, Wright R. Serologic reactions to gluten and cows' milk proteins in gastrointestinal disease. Gastroenterology 1964; 46: 99-108.

20 Harrison M, Kilby A, Walker-Smith J A, France N E, Wood C B. Cows' milk protein intolerance: a possible association with gastroenteritis, lactose intolerance, and IgA deficiency. $\mathrm{Br}$ Med J 1976; i: 1501-4.

21 Shah F H, Yadav M. Maternal and cord serum immunoglobulins in four Malaysian races. Singapore Med $J$ 1977; 18: 246-57.

22 Lebenthal E. Cows' milk protein allergy. Pediatr Clin North Am 1975; 22 : 827-33.

Correspondence to Dr M Yadav, Department of Genetics and Cellular Biology, University of Malaya, Kuala Lumpur, Malaysia.

Received 5 September 1979 